\title{
LA -4976-MS
}

AN INFORMAL REPORT
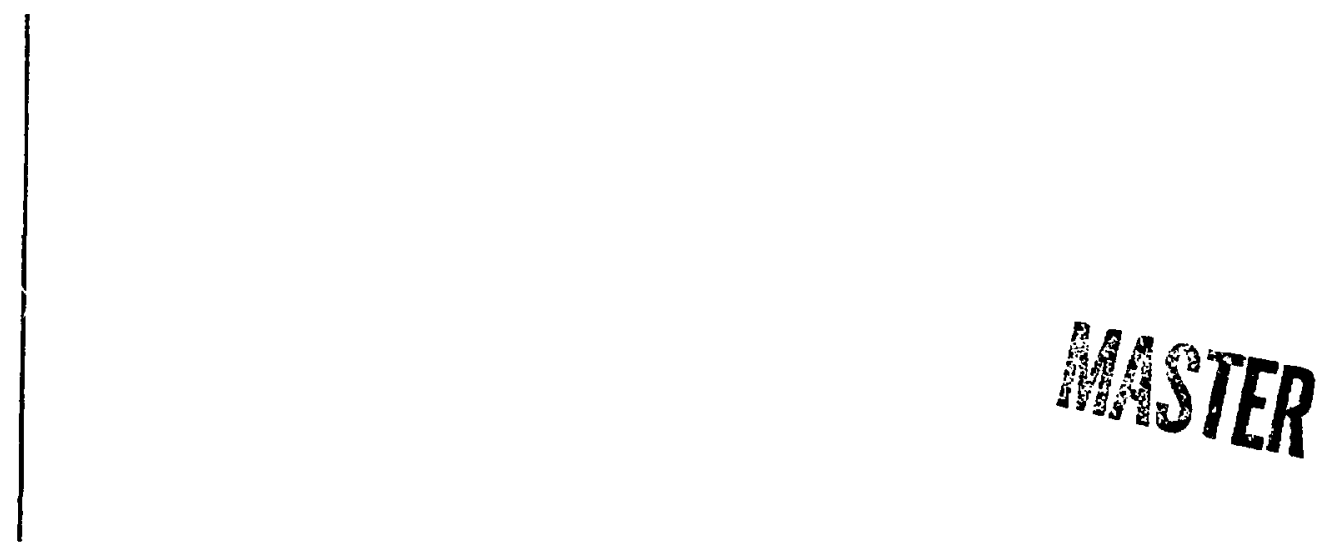

Data Sheets for PMC Radioisotopic Fuel

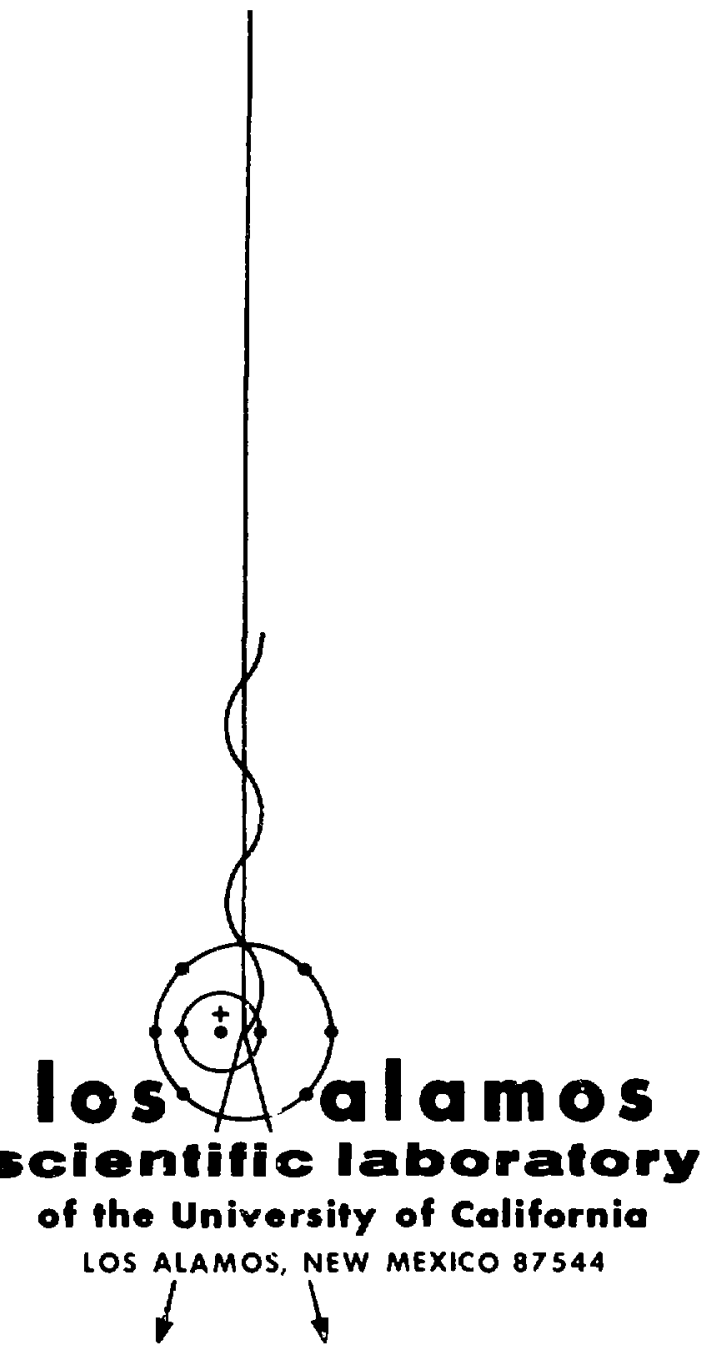


This report was prepared as an accouni of work sponsored by the United States Government. Neither the United States nor the United States Atomic Energy Commission, nor any of their e.nployees, nor any of their contractors, subcontracrors, or their employees, makes any warranty, express or implied, or assumes any legal liability or responsibility for the accuracy, completeness or usefulness of any information, apparatus, product or process disclosed, or represents that its use would not infringe privately owned rights.

In the interest of prompt distribution, this LAMS report was not edited by the Technical Information staff.

Printed in the United States of America. Available from National Technical Information Service

U. S. Department of Commerce 5285 Port Royal Road

Springfield, Virginia 22151

Price: Printed Copy \$3.00; Microfiche $\$ 0.95$ 
LA-4976-MS

An Informal Report UC-4

ISSUED: June 1972

\section{Data Sheets for PMC Radioisotopic Fuel*}

by

T. K. Keenan

R. A. Kent

R. N. R. Mulford

"Supported by Isotopes Technology Branch, Space Nuclear Systems Division, AEC.

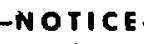

This report was prepared as an account of work sponsored by the United States Government. Neither the United States nor the United States Atomic Energy Commisuion, nor any of their employees, nor any of their contractors, subcontractors, or their employees, makes any warranty, express or implied, or assumes any legal liability or zesponsibility for the accuracy, compieteness or usefulness of any information, apparatus, product or process disclosed, or represents that its use would not infringe privately owned rights. 
DATA SHEETS FOR PMC RADIOISOTOPIC FUEL

by

T. K. Keenan, R. A. Kent, and R. N. R. Nulford

\begin{abstract}
PNC is the acronym for Plutonia Molybdenum Cermet. Plutonia, $\mathrm{PuO}_{2}$, forms the ceramic phase of the cermet and contains $\sim 80$ atom $\%{ }^{234} \mathrm{Pu}$. Molybdenum is the metallic phase of the cermet. The thermal energy resulting from the radioactive decay of the ${ }^{238} \mathrm{Pu}$ isotope is converted into usable elentrical power for space probe or other applications.

The basic cermet module is a disk $2.145 \mathrm{in}$. diam and $0.212 \mathrm{in.} \mathrm{thick.} \mathrm{The} \mathrm{ceramic} \mathrm{phase}$ is nominally 83 wt $\%$ with the nolybdenum contributing the balance of the weight. Stacks of disks are encapsulated in suitable containers to form the working heat source.

The following document lists the characteristics of this cermet with primary emphasis placed on proposed operational conditions and environments. L.ASL was responsible for the majority of the properties determinations and carried out some production support. Mound Laboratory, operated by the Morisanto Research Corp. (MRC) was responsible for the majority of disk production. Representative samples of cermet from both laboratories were used in many determinations.
\end{abstract}


1. Composition

a. Plutoniurn

\begin{tabular}{|c|c|c|}
\hline Isotope & $w t / o$ & Half life $(\mathrm{Yr})$ \\
\hline${ }^{236} \mathrm{Pu}$ & $\sim 0.0001$ & 2.8 \\
\hline${ }^{238} \mathrm{Pu}$ & $80^{(1)}$ & $87.80 \pm 0.02$ \\
\hline${ }^{239} \mathrm{Pu}$ & 16.5 & $2.4 \times 10^{1}$ \\
\hline${ }^{240} \mathrm{Pu}$ & 2.5 & $6.6 \times 10^{3}$ \\
\hline${ }^{241} \mathrm{PLi}$ & 0.8 & 13.0 \\
\hline${ }^{242} \mathrm{Pu}$ & 0.1 & $3.7 \times 10^{5}$ \\
\hline
\end{tabular}

b. $\underline{\text { Oxide }}$

$\begin{array}{lccc} & \text { Min. wt/o } & & \text { Max. wt/o } \\ \mathrm{Pu} & 88.15 & 88.36 \\ \mathrm{O} & 11.64 & 11.85\end{array}$

O/Pu ratio $1.96-2.00$

c. Cermet

$\begin{array}{lcc} & \text { Min. wt/o } & \text { Max.wt/o } \\ {_{2}} } & 81 & 84 \\ \mathrm{Mo} & 16 & 19\end{array}$

d. Impurities

The analysis reported in the following secti, i repres it averages of inalytical studies carried out by both MRC and LASL.

\section{1) Actinide Impurities}

$\begin{array}{cc}\text { Element } & \frac{w t / o}{0.14} \\ \text { Th } & 0.74 \\ \text { U } & 0.09 \\ \text { Np } & 0.06 \\ \text { Am } & \end{array}$

\section{2) Common Impurities}

\begin{tabular}{|c|c|c|}
\hline Element & $\begin{array}{l}\text { Specified Impurity } \\
\text { Level (2) (ppm) }\end{array}$ & Typical Analyses ${ }^{(3)}$ (ppm) \\
\hline Al & 400 & $<54$ \\
\hline $\mathrm{Ca}$ & 500 & $<20 F$ \\
\hline $\mathrm{Co}$ & 250 & $<53$ \\
\hline $\mathrm{Cr}$ & 350 & $<52$ \\
\hline $\mathrm{Cu}$ & 300 & $<50$ \\
\hline $\mathrm{Fe}$ & 500 & $<346$ \\
\hline$M ! g$ & 50 & $<40$ \\
\hline $\mathrm{Na}$ & 250 & $<250$ \\
\hline $\mathrm{Ni}$ & 200 & $<50$ \\
\hline Si & 300 & $<53$ \\
\hline$F$ & & $<100$ \\
\hline $\mathrm{Cl}$ & & $<100$ \\
\hline $\mathrm{Ta}$ & & $<200$ \\
\hline
\end{tabular}

2. Specific Power and Power Density of Typical Cermei ${ }^{2)}$
a. $0.31+0.4$ watts per giam
b. $10.0+1.0$ curies per gram
c. $3.2 \stackrel{+.4}{0.4}$ watts per cc
d. $30+0_{-0}^{+4}$ curies per watt

3. Radiation.

a. Alpha Energy (MeV) Particles/watt-sec
1.
5.491
$7.95 \times 10^{11}$
2. $\quad 5.448$
$3.20 \times 10^{11}$
3.
5.352
$1.5 \times 10^{9}$
4. $\quad 5.200$
$5.0 \times 10^{7}$
5.
5.000
$7.0 \times 10^{4}$
6.
4.700
$1.3 \times 10^{6}$

b. Beta - None

c. Gamma Energy (MeV) Photons/watt-sec

$\begin{array}{lll}1 . & 0.015(\mathrm{~L} \mathrm{X}-\mathrm{ray}) & 1.5 \times 10^{11} \\ 2 . & 0.043 & 4.4 \times 10^{8} \\ 3 . & 0.099 & 1.0 \times 10^{8} \\ 4 . & 0.150 & 1.2 \times 10^{7} \\ 5 . & 0.203 & 4.4 \times 10^{4} \\ 6 . & 0.760 & 5.8 \times 10^{5}\end{array}$

d. Bremsstrahlung - Negligible Particles/

e. Neutrons Source Energy(MeV) watt-sec

1. Spontaneous Flssion $0-10, \quad 4.7 \times 10^{3}$ Av. $=\mathbf{2 . 0}$

2. (a/n) Reactions, Light elements only. At $Z=14$, the cou- See Table I lomb barrier reaches $5.5 \mathrm{MeV}$.

3. Oxygen - 18 content shall be such that the neutron emission rate shall be no greater than $1 \times 10^{4}$ neutrons per second per gram of $\mathrm{Pu}$

4. Total neutron emisas $53 \times 10^{4} \mathrm{n} / \mathrm{sec} / \mathrm{g} \mathrm{Pu}$. 


\section{TABLE I}

Specific Neutron Yields from Light Element

$$
\text { Impurities in }{ }^{238} \mathrm{Pu}^{(4)}
$$

\section{Element}

\section{Neuirons per second for $1 \mathrm{ppm}$}

Li

$\mathrm{Be}$

B

C

$\mathrm{N}$

O

F

$\mathrm{Na}$

Mg

Al

Si

1

$S$

\section{Critical Mlass}

Transport calculations ${ }^{(5)}$ indicate the mass of a bare critical sphere of PMC to be $47.5 \mathrm{~kg}$. Such a sphere would contain $35 \mathrm{~kg}$ of plutonium, of which $28 \mathrm{~kg}$ would be ${ }^{238} \mathrm{Pu}$. The presence of a thick $(16 \mathrm{~cm})$ iron reflector would reduce these values by one-half. Calculated partial densities of the sermel components are:

$$
\begin{array}{ll}
{ }^{238} \mathrm{Pu} & : 6.413 \mathrm{~g} / \mathrm{cc} \\
{ }^{239} \mathrm{Pu}: & 1.61 \mathrm{~g} / \mathrm{cc} \\
\text { Mo } \quad 1.854 \mathrm{~g} / \mathrm{cc} \\
\text { Oxugen: } 1.024 \mathrm{~g} / \mathrm{cc}
\end{array}
$$

\section{Compatibility}

One set of compatibility lests with PMC was designed to examine the interaction of the fuel with Ta-10 W and T-111 (90 Ta-8 W-2 Hf) alloys. It is believed that the major mechanis $m$ of interaction between plutonium oxide and the tantalum alloys is the transfer of oxygen from the fuel to the solid solution and/or precipitation of the oxygen in the allor with possible concomitant changes in the properties of the alloy. The compatibility test capsules were designed to simulate the Transit/Pioneer type of capsule. the ratio of fuel mass to tantalum mass being about 0.9 in the tests. Each test capsule consisted of a T-111 disk completely enclosed (welded) within a 0.020 in. wall Ta-10 $\mathrm{W}$ can. The can was ield in contact with a PMC fuel pellet and the assembly was sealed within a Mo container. Oxygen transport from the fuel to the $T-111$ thus had to lake place through the $\mathrm{Ta}-10 \mathrm{~W}$, as is the case in the Transit/Pioneer heat source. After being held at

\begin{tabular}{|c|c|c|c|c|c|}
\hline \multirow{3}{*}{ 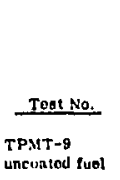 } & \multicolumn{4}{|c|}{ 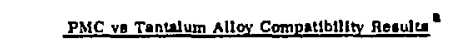 } & \multirow[b]{2}{*}{$\begin{array}{l}\text { Oxygen Content } \\
\text { Chunge (wt ppen }\end{array}$} \\
\hline & $\begin{array}{c}\text { Temperatur } \\
\text { ( }{ }^{\circ} \mathrm{C} \text { ) } \\
\end{array}$ & $\begin{array}{l}\text { - Time } \\
- \text { (hrl }\end{array}$ & Alloy & $\begin{array}{l}\text { Hardnefs Chargo } \\
\text { (DPHE avg) }\end{array}$ & \\
\hline & 1050 & 500 & $\underset{T-111}{T a-10 \mathrm{~W}}$ & $\begin{array}{l}18610236 \\
19760252\end{array}$ & $\begin{array}{l}45 \text { to } 540 \\
75 \text { to } 2500\end{array}$ \\
\hline $\begin{array}{l}\text { TFut }-10 \\
\text { contud faol }\end{array}$ & 1050 & 1000 & $\begin{array}{l}T R-10 W \\
T-111\end{array}$ & $\begin{array}{l}189 \text { to } 199 \\
200 \div 212\end{array}$ & $\begin{array}{ll}20 \text { L } & 40 \\
75 \text { to } & 90\end{array}$ \\
\hline $\begin{array}{l}\text { TPMT-11 } \\
\text { wisonted fuel }\end{array}$ & 810 & 3523 & $\begin{array}{l}T A-10 W \\
T=111\end{array}$ & $\begin{array}{l}205 \text { w } 260 \\
216 \text { to } 238\end{array}$ & $\begin{array}{ll}65 \text { to } & 430 \\
25 \text { to } & 110\end{array}$ \\
\hline $\begin{array}{l}\text { TPNT-12 } \\
\text { unconled fuel }\end{array}$ & 900 & 25as & $\begin{array}{l}T a-10 w \\
T-111\end{array}$ & $\begin{array}{l}210 \text { to } 225 \\
210 \text { to } 218\end{array}$ & $\begin{array}{l}65 \text { w } 150 \\
60 \text { w }\end{array}$ \\
\hline $\begin{array}{l}\text { TPNT } 13 \\
\text { uncontod fuel }\end{array}$ & 1050 & 3034 & $\begin{array}{l}T=-10 W \\
T=111\end{array}$ & $\begin{array}{l}102 \text { to } 202 \\
204 \text { to } 240\end{array}$ & $\begin{array}{l}=10 \quad 320 \\
=-101000\end{array}$ \\
\hline $\begin{array}{l}\text { TPMT-14 } \\
\text { so coated tuel }\end{array}$ & 1050 & $748 B$ & $\begin{array}{l}T n-10 w \\
T-111\end{array}$ & $\begin{array}{l}277 \text { w265 } \\
273 w 268\end{array}$ & $\begin{array}{lr}30 \text { w } & 110 \\
15 \text { to } & 20\end{array}$ \\
\hline
\end{tabular}
temperature for various lengths of time, the oxygen contents of the tantalum alloy parts was determined by chemical analysis. Microhardness measurements were also made. Test results are below:

\section{PMC - Ir Compatibllity Results}

Another series of tests of PMC fuel against iridium was done. The configuration consisted of a PMC pellet enclosed in a welded $\mathrm{Ir}$ container. In the tests listed as "vented" a slot in the Ir allowed gaseous communication between the container interior and exterior. The Ir container was sealed within an external tantalum container. At the relatively high temperatures of these tests, it was found that an iridium-molybdenum intermetallic compound was formed on all Ir inner surfaces. It is inferred that the mechanism of interaction between PMC and Ir consists of gaseous Mo transport via volatile Mo oxjde gasesous spectes, the oxygen being supplied by the plutonium oxide constituent of the PMC. The tests are listed below: 


\section{$\underline{P M C}$ - Ir Tests}

\begin{tabular}{rrrrrr} 
Test No. & Temp. & Time & Configuration & Result \\
\cline { 1 - 3 } MHW-13 & 1370 & 995 & vented & Mo-Ir reaction \\
MHW-15 & 1370 & 995 & unvented & MO-Ir reaction \\
MHW-16 & 1500 & 1012 & vented & Mo-Ir reaction
\end{tabular}

\section{Thermophysical Properties}

a. Density equation - Not available

b. Coefficients for thermal expansion (estimated) The following estimated equation for thermal expansion is assumed valid in view of the very good agreement between estimated and measured values for $\mathrm{SSC}$. ${ }^{(5)}$ $\Delta \mathrm{L} / \mathrm{L}-2.225 \times 10^{-3}+11.45 \times i^{-6} \mathrm{~T}\left({ }^{\circ} \mathrm{C}\right),\left(200-2000^{\circ} \mathrm{C}\right)$.

c. Specific heat and entropy (estimated for cermet, $\left.83^{\mathrm{wt}} / \mathrm{O} \mathrm{PuO}_{2}, 17^{\mathrm{wt}} / \mathrm{o} \mathrm{Mo}\right)$. Values are given in Table II.

$\mathrm{C}_{\mathrm{p}}\left(\mathrm{cal} / \mathrm{g}-{ }^{\circ} \mathrm{C}\right)=0.069+15.0 \times 10^{-6} \mathrm{~T}$

$-5.24 / \mathrm{T}^{2}$

$\mathrm{H}_{\mathrm{T}}^{\mathrm{o}}-\mathrm{H}_{25^{\circ} \mathrm{C}}^{\mathrm{o}}=\sum_{25}^{\mathrm{o}} \mathrm{C} \quad \mathrm{C}_{\mathrm{p}} \mathrm{dT}$

\section{TABLE II}

Thermodynamic Values for PMC

\begin{tabular}{|c|c|c|}
\hline Temp., ${ }^{0} \mathrm{C}$ & cal $/ g-\operatorname{deg} C$ & $\begin{array}{l}\mathrm{H}_{\mathrm{T}}^{\mathrm{O}}-\mathrm{H}^{\mathrm{O}}{ }_{25^{\circ} \mathrm{C}} \\
\mathrm{cal} / \mathrm{g}\end{array}$ \\
\hline 25 & 0.061 & 0 \\
\hline 500 & 0.076 & 34 \\
\hline 1000 & 0.084 & 75 \\
\hline 1500 & 0.091 & 118 \\
\hline 2000 & 0.099 & 166 \\
\hline
\end{tabular}

d. Temperatures of phase transformations ${ }^{(6)}$

1. The ceramic phase melts at $2365 \pm 30^{\circ} \mathrm{C}$ (solidus) vs $2400 \pm 20^{\circ} \mathrm{C}$ for pure $\mathrm{PuO}_{2}$.

2. The Mo metal phase melts at $2615 \pm 20^{\circ} \mathrm{C}$.

e. Latent heats of phase transformations $(6,7)$

1. The heat of melting for the ceramic phase is $65 \mathrm{cal} / \mathrm{g}$.
2. The heat of melting for the Mo metal phase is $69 \mathrm{cal} / \mathrm{g}$.

3. The heat of sublimation for the ceramic phase is $490 \pm 10 \mathrm{cal} / \mathrm{g}$.

4. The heat of sublimation for the Mo metal phase is $1640 \pm 10 \mathrm{cal} / \mathrm{g}$.

\section{f. Vapor Pressures}

\section{Plutonia}

Plutonia undergoes congruent vaporization to yield gaseous $\mathrm{PuO}, \mathrm{PuO}_{2}, \mathrm{O}$ and $\mathrm{O}_{2}$ above solid $\mathrm{PuO}_{2-\mathrm{x}}$, the value of $\mathrm{x}$ depending on the temperature. Values for the congruently vaporizing composition as a function of temperature are:

\begin{tabular}{cc} 
Temp. ${ }^{\circ} \mathrm{C}$ & $\begin{array}{c}\text { Congruently Vaporizing } \\
\text { Composition }\end{array}$ \\
\cline { 2 - 2 } 1327 & $\mathrm{PuO}_{1} \cdot 82$ \\
1527 & $\mathrm{PuO}_{1} \cdot 89$ \\
1727 & $\mathrm{PuO}_{1 \cdot 86}$ \\
1927 & $\mathrm{PuO}_{1} \cdot 85$ \\
2127 & $\mathrm{PuO}_{1} \cdot 84$
\end{tabular}

Mass spectrometric - Knudsen effusion studies performed at LASL yield for $\mathrm{PuO}$ and $\mathrm{PuO}_{2}$ gases above plutonia, the vapor pressure equations

$$
\begin{aligned}
& \log _{10} \mathrm{P}_{\mathrm{PuO}}(\mathrm{atm})=6.806-28257 / \mathrm{TOK} \text { and } \\
& \log _{10} \mathrm{P}_{\mathrm{PuO}_{2}}(\mathrm{~atm})=7.687-29928 / \mathrm{TOK} .
\end{aligned}
$$

These equations yield

$$
\log _{10} P_{E}(\mathrm{~atm})=7.557-29096 / \mathrm{T}^{\circ} \mathrm{K} \text {, }
$$

where $\mathrm{PE}_{\mathrm{E}}=\mathrm{P}_{\mathrm{PuO}_{2}}+\left(\mathrm{M}_{\mathrm{PuO}_{2}} / \mathrm{M}_{\mathrm{PuO}}\right)^{11}{ }_{2} \mathrm{P}_{\mathrm{PuO}}$. The heat and entrapy of vaporization for $P_{E}$ are $493 \pm 10 \mathrm{cal} / \mathrm{g}$ and $0.13 \pm 0.02 \mathrm{cal} / \mathrm{g}-{ }^{\circ} \mathrm{C}$, respectively

$$
\text { 2. PMC }
$$

The vaporization behavior of a number of PMC samples has been studied by means of mass spectrometric-Knudsen ffusion techniques. The results for a typical PMC sample in the range oi $500-2100^{\circ} \mathrm{C}$ are listed in the following table. Except for the gaseous PuO and $\mathrm{PuO}_{2}$ produced at high temperatures. all of the vapor pressures are nonequilibrium and transitory and decrease with time. The data listed in the table for these transitory species are the initial values for the temperature stated. 
YAPOR APECIES FROM PMC

\begin{tabular}{|c|c|c|c|}
\hline$T=500^{\circ} \mathrm{C}$ & & $T=65^{\circ}$ & \\
\hline specier & 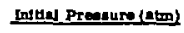 & spection & IntHel Prenture (atm) \\
\hline H• & $2.0 \times 10^{-5}$ & Ho & $7.8 \times 10^{-4}$ \\
\hline $\mathbf{H}_{\mathbf{3}}$ & $6.0 \times 10^{-1}$ & $\mathbf{H}_{\mathbf{2}}$ & $7.8 \times 10^{-1}$ \\
\hline $\mathrm{B}_{\mathbf{1}} \mathrm{O}$ & $1.5 \times 10^{-1}$ & $\mathrm{H}_{\mathbf{3}} \mathrm{O}$ & $1.0 \times 10^{-1}$ \\
\hline $\mathrm{HF}$ & $2,0 \times 10^{-1}$ & HF & $6.2 \times 10^{-1}$ \\
\hline HC1 & $0.0 \times 10^{-1}$ & HC1 & $1.6 \times 10^{-1}$ \\
\hline Ar & $3.4 \times 10^{-7}$ & $\mathbf{c t}_{\mathbf{i}}$ & $2.3 \times 10^{-1}$ \\
\hline & & Ar & $3.0 \times 10^{-1}$ \\
\hline & & MoF, & $1.2 \times 10^{-1}$ \\
\hline & & MoCl, & $1.6 \times 10^{-1}$ \\
\hline
\end{tabular}

$\tau=775^{\circ} \mathrm{c}$

Species

He

H.

$\mathrm{H}_{8} \mathrm{O}$

HF

tycl

Ar

Mor.

Moct,

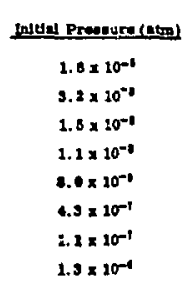

$T=m 8^{\circ} \mathrm{C}$

spectes

H*

H.

H,O

HF

HCI

$\mathrm{Cl}_{1}$

As

Moct.

$T=114^{\circ} \mathrm{C}$

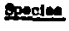

Ho

$\mathrm{F}_{2}$

$\mathrm{H}_{2} \mathrm{O}$

HCI

cl,

AT

Mor,

Moct,

PuF, -

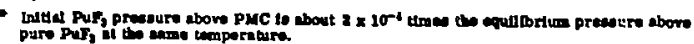

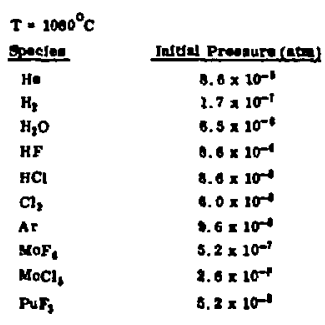

$\mathrm{T} * 1802^{\circ} \mathrm{C}$

speciee

110
$\mathrm{H}_{2}$
$\mathrm{H}_{2} \mathrm{O}$

HF

HCI

Al:

Mor.

Mocl.

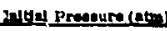

$3.1 \times 10^{-4}$

$1.2 \times 10^{-9}$

$8.0 \times 10^{-1}$

$0.3 \times 10^{-0}$

$1.2 \times 10^{-1}$

$0.3 \times 10^{-1}$

9. $5 \times 10^{-1}$

$9.9 \times 10^{-1}$

$2.8 \times 100$

Indelel Prenure (abp)

$3.1 \times 10^{-4}$

$2.1 \times 10^{-1}$

$1.4 \times 10^{-1}$

$1.7 \times 10^{-4}$

$8.1 \times 10^{-1}$

$1.5 \times 10^{-4}$

$1.6 \times 10^{-4}$

$1.7 \times 10^{-1}$

$1.5 \times 10^{-1}$
$2.1 \times 10^{-1}$

Specion

H.

$\mathrm{H}_{2}$

$\mathrm{H}_{2} \mathrm{O}$

HF

HCI

$\mathrm{cl}_{\mathbf{1}}$

Ar

MoCl,

$T=2009^{\circ} \mathrm{C}$

streles

He

$\mathrm{H}_{\mathbf{3}}$

HF

HCl

$\mathrm{Cl}_{1}$

Ar

Mor.

$T-126^{\circ} \mathrm{C}$

spocten

H.

$\mathrm{H}_{2}$

$\mathrm{H}_{2} \mathrm{O}$

HF

HCI

$\mathrm{Cl}_{2}$

AF

Mor.

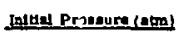

$1.7 \times 10^{-1}$

$1.4 \times 10^{-1}$

$0.9 \times 10^{-1}$

$1.3 \times 10^{-3}$

$1.4 \times 10^{-1}$

$1.0 \times 10^{-1}$

$3.0 \times 10^{-1}$

$1.2 \times 10^{\text {"1t }}$

$0.5 \times 10^{-4}$

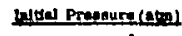

$1.3 \times 10^{-1}$

$1.2 \times 10^{-4}$

$0.1 \times 10^{-1}$

$7.2 \times 10^{-3}$

$1.2 \times 10^{-1}$

$0.4 \times 10^{-4}$

s. $2 \times 10^{-1}$

$1.3 \times 10^{-1}$

$1.1 \times 10^{-1}$

Inten Prenoure(ats)

$0.1 \times 10^{-1}$

$1.2 \times 10^{-1}$

$4.0 \times 10^{-4}$

$5.6 \times 10^{-9}$

$0.1 \times 10^{-3}$

$3.7 \times 10^{-1}$

$9.2 \times 10^{-4}$

$9.0 \times 10^{-1}$

$1.0 \times 10^{-1}$

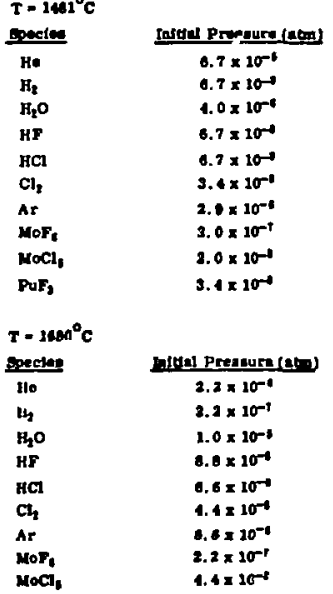

Above $1600^{\circ} \mathrm{C}$, the degassing of the PMC sample

is near completion and the only vapor species observed in significant amounts other than He, are the equilibrium species $\mathrm{PuO}$ and $\mathrm{PuO}_{2}$. Values for $\mathrm{P}_{\mathrm{E}}$ for $\mathrm{PMC}$ are compared with those calculated for plutonia below.

$\underline{T^{\circ} \mathrm{C}} \quad \underline{\mathrm{PE}(\mathrm{atm})-\mathrm{PMC}}$

$\begin{array}{lll}1602 & 1.16 \times 10^{-8} & 1.09 \times 10^{-8} \\ 1680 & 4.56 \times 10^{-8} & 4.56 \times 10^{-8} \\ 1759 & 1.72 \times 10^{-7} & 1.73 \times 10^{-7} \\ 1675 & 4.28 \times 10^{-8} & 4.18 \times 10^{-8} \\ 1778 & 2.21 \times 10^{-8} & 2.35 \times 10^{-7} \\ 1834 & 5.51 \times 10^{-8} & 5.59 \times 10^{-7}\end{array}$

g. Thermal Conductivity (estimated) $\mathrm{k}\left(\mathrm{cal} / \mathrm{cm}-\sec -{ }^{0} \mathrm{C}\right)=0.027-7.0 \times 10^{6} \mathrm{~T}$ $\left({ }^{\circ} \mathrm{C}\right),\left(25-2000^{\circ} \mathrm{C}\right)$.

h. Thermal diffusivity (estimated)

$\alpha\left(\mathrm{cm}^{2} / \mathrm{sec}\right)=0.036-11.0 \times 10^{-6} \mathrm{~T}\left({ }^{\circ} \mathrm{C}\right)$, $\left(25-2000^{\circ} \mathrm{C}\right)$.

i. Viscosity (estimated)

The viscosity of the ceramic phase is estimated to be 32 centipoise ( $\$ 25 \%)$ at the mel:ing point.

f. Surface tension

1. The surface tension of the ceramic phase is 523 dyne/cm ( $\pm 15 \%$ ) at the melting point. (8)

2. The surface tension of the Mo metal phase is 2080 dyne/cm at the melting point. (9)

k. Total hemispherical emittance - Not available.

1. Spectral emissivity

The spectral emissivity for Mo is 0.38 at $1700^{\circ} \mathrm{C}$ (wavelength $=0.467 \mu$ ). (9) Preliminary data yield 0.7 for the emittance of PMC. (6) .

m. Crystallography

The ceramic phase has FCC structure with a lattice parameter of $5.9350 \pm 0,0005 \%$. when corrected for self-heating affects. (6)

The Mo metal phase has BCC structure: with a lattice parameter of $3.1468 \pm 0.0005{ }^{\circ}$. (10) 
n. Solubility in sea water

The accompanying table shows the amount of plutonium, in $\mu \mathrm{g}$ per $\mathrm{mm}^{2}$ of PMC surface area, dissolved from a $1 / 2-i n$. dia PMC specimen during the stated times of exposure in 75 liters of synthetic seawater. (11)

\begin{tabular}{|c|c|}
\hline $\begin{array}{l}\text { Time } \\
\text { (days) }\end{array}$ & $\begin{array}{l}\text { Total } \mathrm{Pu} \text { in Seawater } \\
\left(\mu \mathrm{g} / \mathrm{mm}^{2}\right) \\
\end{array}$ \\
\hline 0.1 & $2.1 \times 10^{-2}$ \\
\hline 1 & 4.0 \\
\hline 5 & 4.13 \\
\hline 10 & 4.17 \\
\hline 20 & 4.64 \\
\hline 35 & 5.38 \\
\hline 50 & 6.00 \\
\hline 70 & 6.57 \\
\hline
\end{tabular}

o. Helium Migration

\section{Release Rates}

Heli um release rate data are available from four PMC disks. The data have been fitted by a mathematical model developed from classical diffusion theory. The model describes the helium content of the fuel by the following equation:

$\frac{Q}{Q_{0}}=\frac{6}{\pi^{2}} \sum_{n=1}^{\infty} \frac{1}{n^{2}} \exp \left(-n^{2} \pi^{2} D^{1} t\right)-\frac{B}{D^{1} C_{0}} \frac{6}{\pi^{4}} \sum_{n=1}$

$\frac{1}{n^{4}} \exp \left(-n^{2} \pi^{2} D^{1} t\right)+\frac{B}{15 D^{1} C_{o}}$

where $Q$ is the quantity of hellum in the sample $\left[\operatorname{cc}(\mathrm{STP}) \mathrm{g}^{-1}\right]$ at time $\mathrm{t}(\mathrm{sec})$,

$Q_{0} \quad$ is the quantity of helium in the sample at $\mathrm{t}=0$,

$D^{1} \quad$ is the effective diffusion coefficient $\left(\sec ^{-i}\right)$,

$B$ is the (constant) helium generation rate $\left[\operatorname{cc}(\mathrm{STP}) \mathrm{g}^{-1}\right]$, and

$\mathrm{C}_{0}$ is the uniform concentration at $\mathrm{t}=0$ $\left[\operatorname{cc}\left(\mathrm{STP}^{\mathrm{P}}\right) \mathrm{g}^{-1}\right]$.

The effective diffusion coefficients, $D^{1}$, were determined for each of the disks by the best fit of the data to the model. The values obtained are listed in the following table.

\begin{tabular}{lccc} 
Ditak No. & Temp. $\left({ }^{\circ} \mathrm{C}\right)$ & $\frac{D^{1}\left(\sec ^{-1}\right)}{\text { Thme in costideys) }}$ \\
\cline { 2 - 2 } & 800 & $1.5 \times 10^{-10}-1 \times 10^{-1}$ & 402 \\
PMB-74 & 800 & $1 \times 10^{-1}$ & 192 \\
PM-89T & $85:$ & $1.2 \times 10^{-9}$ & 283 \\
PFT-88 & 850 & $3 \times 10^{-3}$ & 67
\end{tabular}

- Through soo daya the hellum content predicted by a $D^{\prime}$ of $1.5 \times 10^{-1} 1 \mathrm{sec}^{-1}$ was in rosmonably good agreement with the experimental value for this disk. The belfum rolease rate then changed vory rapldy so thet $1 \mathrm{D}^{1}$ of $1 \times 10^{-1} \mathrm{eec}^{-1}$ throughout the duration of the experiment was neceusery to obtoin the helfum content of the fuel at 402 day..

\section{Microstructural Effects}

Helium movement and observable helium release begin at temperatures above $500^{\circ} \mathrm{C}$. It is thus assumed that fuel storage at temperatures below $500^{\circ} \mathrm{C}$ results in the interstitial accumulation of helium in the solid. When the temperature is raised, not only is gaseous helium released but bubbles form in the ceramic grain boundaries of the fuel. At temperatures in the approximate range 700 to $1100^{\circ} \mathrm{C}$, the general effect appears to be a separation of grain boundaries which could affect the mechanical properties of the fuel. At higher temperatures the bubbles migrate along grain boundaries and coalesce.

The formation of bubbles in the fuel is accompanied by some swelling. The maximum linear increase attributable to bubble formation observed in PMC fuel has been about $1 \%$.

The fuel from Pioneer capsule PF-1 which had operated for 219 days at $800-850^{\circ} \mathrm{C}$ exhibited no helium bubble formation but had swelled about $0.6 \%$, linear.

7. Mechanical Properties

a. Hardness

At $25^{\circ} \mathrm{C}$ the hardness for the Mo metal phase is approximately $150 \mathrm{DPH}$, that for the $\mathrm{PuO}_{2}$ ceramic phase is approximately $850 \mathrm{DPH}{ }^{(6)}$

\section{b. Impact}

The results of impact tests on PMC samples after various treatments are given below. The samples consisted of discs $0.5^{\prime \prime}$ in diameter by approximately 0.21 " thick. 


\begin{tabular}{|c|c|c|c|}
\hline \multirow[b]{2}{*}{ Semple Yo. } & \multicolumn{3}{|c|}{ Inpect Tests on PMC } \\
\hline & Condtion & Exaction<104 & Fructon $<1 \mu$ \\
\hline $111-\mathrm{A}$ & as fabricated & 0.012 & n.d.* \\
\hline $111-B$ & as fabrtcated & 0.008 & 0.0018 \\
\hline n1-c & 82 days at $\$ 15^{\circ} \mathrm{C}$ & 0.022 & 0.0024 \\
\hline $117-1$ & as fubricated & 0.010 & n.d. * \\
\hline $117-2$ & 75 days at $1370^{\circ} \mathrm{C}$ & 0.027 & 0.0043 \\
\hline PMT-67-A & $\begin{array}{l}42 \text { daye at } 815^{\circ} \mathrm{C} \\
\text { plua reantry puleo to } \\
1400^{\circ} \mathrm{C}\end{array}$ & 0.023 & 0,0027 \\
\hline $2 \mathrm{MIT}-67-\mathrm{B}$ & $\begin{array}{l}42 \text { days ot } 811^{\circ} \mathrm{C} \\
\text { plus roentry puldeo to } \\
1400^{\circ} \mathrm{C}\end{array}$ & 0.021 & n.d." \\
\hline PMT-67-E & as fabricatod & 0.008 & 0.00085 \\
\hline PMT-67-F & as tabricatod & 0.015 & 0.0012 \\
\hline
\end{tabular}

\section{Chemical Properties}

a. The heat and entropy of formation for the ceramic phase at $25^{\circ} \mathrm{C}$ are $-935 \pm 10 \mathrm{cal} / \mathrm{g}$ and $0.16 \mathrm{cal} / \mathrm{g}-$ ${ }^{\circ} \mathrm{C}$, respectively.

b. Chemical Reactions -- based on thermodynamic calculations. The thermodynamic values are taken from a number of sources. $(12-15)$

\section{Water}

Water vapor does not react with $\mathrm{PuO}_{2} \cdot 00$ below $2000^{\circ} \mathrm{C}$. At lower temperatures, water vapor can oxidize $\mathrm{PuO}_{2-\mathrm{x}}$; see the table under hydrogen. Solubility, as distinct from chemical reaction, is not considered in these statements.

\section{Hydrogen}

Fiydrogen will reduce $\mathrm{PuO}_{2}$. 00 to $\mathrm{PuO}_{2-\mathrm{x}}$, with water vapor as the by-product. Values for $\mathrm{PuO}_{2-\mathrm{x}}$ produced at various temperatures are listed in the accompanying table. Below the listed temperatures, the reaction is reversed and water vapor can oxidize $\mathrm{PuO}_{2-\mathrm{x}}$.

Reaction

$\mathrm{PuO}_{2 \cdot 00}+0.02 \mathrm{H}_{2}=\mathrm{PuO}_{1} \cdot 98+0.02 \mathrm{H}_{2} \mathrm{O}$

$\mathrm{PuO}_{2} \cdot 00+0.05 \mathrm{H}_{2}=\mathrm{PuO}_{1} \cdot 95+0.05 \mathrm{H}_{2} \mathrm{O}$

$\mathrm{PuO}_{2} \cdot 00+0.08 \mathrm{H}_{2}=\mathrm{PuO}_{1} \cdot 92+0.08 \mathrm{H}_{2} \mathrm{O}$

$\mathrm{PuO}_{2} \cdot 90+0.10 \mathrm{H}_{2}=\mathrm{PuO}_{1} \cdot 90+0.10 \mathrm{H}_{2} \mathrm{O}$

$\mathrm{PuO}_{2} \cdot 00+0.15 \mathrm{H}_{2}=\mathrm{PuO}_{1} \cdot 8_{\mathrm{ii}}+0.15 \mathrm{H}_{2} \mathrm{O}$

$\mathrm{PuO}_{2} \cdot 00+0.20 \mathrm{H}_{2}=\mathrm{PuO}_{1 \cdot 80}+0.20 \mathrm{H}_{2} \mathrm{O}$
Minimum Temperature For Reaction To Take Place $1290 \pm 10^{\circ} \mathrm{C}$ $1420 \pm 20^{\circ} \mathrm{C}$ $1520 \pm 20^{\circ} \mathrm{C}$ $1590 \pm 20^{\circ} \mathrm{C}$ $1760 \pm 20^{\circ} \mathrm{C}$ $1920 \pm 20^{\circ} \mathrm{C}$

\section{Oxygen}

There is a dissociative equilibrium between solid $\mathrm{PuO}_{2}$ and gaseous $\mathrm{PuO}, \mathrm{PuO}_{2}, \mathrm{O}$ and $\mathrm{O}_{2}$. However, the dissocjation pressures do not become appreciable below about $1900^{\circ} \mathrm{C}$. At lower temperatures, the reaction of oxygen with $\mathrm{PuO}_{2-\mathrm{x}}$ to form $\mathrm{PuO}_{2}$ is favored.

\section{Carbon}

Carbon will reduce $\mathrm{PuO}_{2}$ to $\mathrm{PuO}_{2-\mathrm{x}}$. The reduced $\mathrm{Pu}$ oxides formed at various temperatures are listed in the accompanying table.
Reaction

$\mathrm{PuO}_{2 \cdot 00}+0.02 \mathrm{C}=\mathrm{PuO}_{1 \cdot 98}+0.02 \mathrm{CO}$
$\mathrm{PuO}_{2} \cdot 00+0.05 \mathrm{C}=\mathrm{PuO}_{1} \cdot 95+0.05 \mathrm{CO}$
$\mathrm{PuO}_{2} \cdot 00+0.10 \mathrm{C}=\mathrm{PuO}_{1} \cdot 90+0.10 \mathrm{CO}$
$\mathrm{PuO}_{2} \cdot 00+0.15 \mathrm{C}=\mathrm{PuO}_{1} \cdot 85+0.15 \mathrm{CO}$
$\mathrm{PuO}_{2 \cdot 00}+0.20 \mathrm{C}=\mathrm{PuO}_{1} \cdot 80+0.20 \mathrm{CO}$
$\mathrm{PuO}_{2 \cdot 00}+0.39 \mathrm{C}=\mathrm{PuO}_{1} \cdot 61+0.39 \mathrm{CO}$

At temperatures above $1900^{\circ} \mathrm{C}$, carbon reacts with $\mathrm{PuO}_{2}$ to form $\mathrm{PuC}_{2}$ and $\mathrm{CO}$.

\section{Nitrogen}

Nitrogen gas does not react with $\mathrm{PuO}_{2}$ below $2000^{\circ} \mathrm{C}$.

\section{Tantalum}

Tantalum metal may react with $\mathrm{PuO}_{2}$ to form $\mathrm{PuO}_{1} \cdot 61$ and $\mathrm{Ta}_{2} \mathrm{O}_{5}$ at $680 \pm 20^{\circ} \mathrm{C}$.

7. Tungsten

Tungsten reacts with $\mathrm{PuO}_{2}$ to form $\mathrm{PuO}_{2-\mathrm{x}}$ and $\mathrm{WO}_{2}$ and/or $\mathrm{WO}_{3}$. The reduced oxides formed are $\mathrm{PuO}_{1} \cdot 98$ at $1300 \pm 20^{\circ} \mathrm{C}, \mathrm{PuO}_{1} \cdot 95$ at $1480 \pm 20^{\circ} \mathrm{C}$, and $\mathrm{PuO}_{1} \cdot{ }_{90}$ at $1700 \pm 20^{\circ} \mathrm{C}$.

\section{Molybdenum}

Molybdenum reacts with $\mathrm{PuO}_{2}$ to form $\mathrm{PuO}_{2-\mathrm{x}}$ and $\mathrm{MoO}_{2}$ and/or $\mathrm{MoO}_{3}$. The reduced oxides formed are $\mathrm{PuO}_{1.98}$ at $1300 \pm 20^{\circ} \mathrm{C}$, and $\mathrm{PuO}_{1} \cdot 95$ at $1630 \pm 20^{\circ} \mathrm{C}$.

\section{Iridium}

Iridium does not react with $\mathrm{PuO}_{2}$. However, there is some evidence that $\mathrm{PuO}_{2-\mathrm{x}}(x \geq 0.1)$, reacts with Ir to form PuIR . 


\section{Titanium}

Titanium metal dues not react with $\mathrm{PuO}_{2}$ below $2000^{\circ} \mathrm{C}$. $\mathrm{TiO}_{2}$ does not react with $\mathrm{PuO}_{2}$, but will react with $\mathrm{PuO}_{2}-\mathrm{x}$ to form $\mathrm{PuO}_{2}$ and $\mathrm{Ti}_{2} \mathrm{O}_{3}$.

11. Hafnium, Thorium and Zirconium

Hafnium, thorium, and zirconium metals will reduce $\mathrm{PuO}_{2}$ to $\mathrm{Pu}$ metal. $\mathrm{HfO}_{2}, \mathrm{ThO}_{2}$, and $\mathrm{ZrO}_{2}$ do not react chemically with $\mathrm{PuO}_{2}$ but may form solid solutions.

12. Biological Tolerances

The radiobiological tolerances for ${ }^{238} \mathrm{Pu}$ are shown in the following table. ${ }^{(16)}$

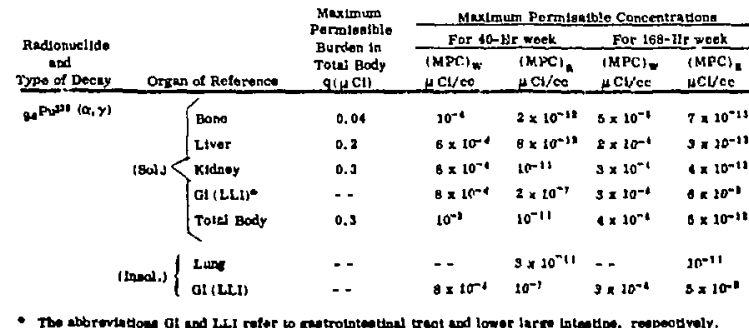

13. Shielding Data

Shielding dita are presented in the following table. $(8,17)$

\begin{tabular}{|c|c|c|c|}
\hline Materin & $\begin{array}{l}\text { Density } \\
(\mathrm{R} / \mathrm{cc})\end{array}$ & $\begin{array}{l}\text { Thicknese Requlred to } \\
\text { Reduce Intensity of } \\
800 \text { keV Gamma Rays to } \\
1 \% \text { of Inctdent Value } \\
\text { (cm) }\end{array}$ & $\begin{array}{l}\text { Attonuating Layer } \\
\left(\mathrm{g} / \mathrm{cm}^{2}\right)\end{array}$ \\
\hline Concrate & 2.35 & 24.4 & 57.34 \\
\hline iron & 7.87 & 8.8 & 69.26 \\
\hline Histelloy C & 8.94 & 7.8 & $69.7 \mathrm{a}$ \\
\hline Haynes Alloy 25 & 9.19 & 7,7 & 70.30 \\
\hline Lond & 11.36 & 4.7 & 53.39 \\
\hline Tantalum & 16.6 & 3.6 & 59.76 \\
\hline Urantum & 10.07 & 2.5 & 47.68 \\
\hline Tungeten & 19.3 & 3.0 & 57.90 \\
\hline
\end{tabular}

b. Attentation Fuctora for Neutron Shlelding Materiala

\begin{tabular}{|c|c|c|c|}
\hline Materfal & $\begin{array}{l}\text { Density } \\
\text { (g/ec) }\end{array}$ & $\begin{array}{l}\text { Thicknese Required to } \\
\text { Reduce intensity of } \\
\text { 1-10 Mev Neutrons to } 0.1 \% \\
\text { of Incident velue } \\
\text { (cm) }\end{array}$ & $\begin{array}{l}\text { A ttenuating Layer } \\
\left(\mathrm{R} / \mathrm{cm}^{2}\right)\end{array}$ \\
\hline Polyetbytene & 0.298 & 50 & 47 \\
\hline Plexiglas & 1.185 & 78 & 92 \\
\hline Paraftin & 0.89 & 60 & 53 \\
\hline Benelex 70 & 1.40 & 50 & 70 \\
\hline
\end{tabular}

\section{$\underline{\text { References }}$}

1. Letter M. Klein AEC/SNS, to F. P. Baranowski, Nov, 18, 1968, "Savannah River Plutonium-238 Dioxide Feed Specification".

2. MRC Document 1-14531, Rev. 2, Nov. 6, 1970, "Plutonium-238 Dioxide Molybdenum Cermet Disc Specification".

3. MRC Reports MLM-1827 and MLM-1887.

4. G. M. Matlack and C. F. Metz, "Radiation Characteristics of Plutonium-238", LASL Document LA$3696,1967$.

5. LASL Document CMB-11-9740, April 15, 1971.

6. Experimental values measured at LASL.

7. Calculated at LASL.

8. MRC Report MLM-1691, 1969

9. C.J. Smithells, Metals Reference Book, Plenum Press, London, 1967.

10. W. B. Pearson, Handbook of Lattice Spacings and Structures of Metals, Peganon Press Ltd., London, 1967.

11. LASL Document CMB-5-C-101, May 12, 1971.

12. R.J. Ackermann, R. L. Faircloth and M.H. Rand, J. Phys. Chem. 70, 3698 (1966).

13. T. L. Mackin and M.H. Rand, Proceedings of the Symposium on Thermodynamics with Emphasis on Nuclear Materials and A tomic Transport in Solids, IAEA, Vienna, 1965, p 145.

14. JANAF Thermochemical Tables, The Dow Chemical Co., Midland, Michigan, 1965 and Supplement.

15. High Temperature Oxides, Part II., edited by A.M. Alper, Academic Press, N.Y. 1970.

16. "Maximum Permissible Body Burdens and Maximum permissible Concentrations of Radionuclides in Air and Water for Occupational Exposure", National Bureau of Standards Handbook 69, p.87.

17. MRC Report, MLM-1564, 1968. 